\title{
Student Motivation in Online English Learning
}

\author{
Andhina Ika Sunardi \\ Akademi Manajemen Administrasi Yogyakarta \\ andhinaika@amayogyakarta.ac.id
}

\begin{abstract}
Article History
Received: 24 September 2021

Reviewed: 13 October 2021

Accepted: 14 October 2021

Published: 30 November 2021
\end{abstract}

Keywords: motivation, English learning, online

\begin{abstract}
This study aims to discover and describe the condition of the motivational object experienced by students in online English learning during the COVID-19 pandemic. This research was conducted in Yogyakarta in the even learning year 2020/2021. Sampling was done using a purposive sampling technique, and four classes were obtained, each of which there was 32 students, with the total number of samples being 128 students. Data collection techniques in this study are by distributing questionnaires, interviews, and documentation. The questionnaire was made using google forms. Data analysis calculated the percentage of each category indicator and learning motivation aspect, from which the data percentage score was interpreted, and each indicator was analyzed in depth. The results of this study indicate that the learning motivation of students in Yogyakarta in the even semester is in the odd category. This can be seen from the moderate category, as many as 72 students out of 128 students, while from the motivational presentation score with the highest ARSC aspect, the satisfaction aspect is $28 \%$. This research is expected to evaluate various parties involved in organizing online learning in universities so that the implementation is more optimal.
\end{abstract}

\section{INTRODUCTION}

By the end of 2020, the COVID-19 pandemic was no longer foreign to the people of Indonesia. The disease caused by this virus causes a large number of deaths. One of the impacts of the COVID-19 pandemic in Indonesia is the education sector. The implementation of education is no longer face-to-face but has been replaced with online learning. There is a difference between student learning motivation and learning outcomes during online learning. Attention from educators, parents, and families is needed to provide motivation, enthusiasm, and support to students. The quality of education is highly dependent on educators. Therefore, educators must improve their quality in carrying out learning in terms of learning techniques, teaching media, and others. 
The quality of education in this pandemic era must be further improved for quality education through educational changes and development. The education system is designed to create qualified and highly competitive alumni to produce graduates who can answer the challenges of the times. For students, learning must always be upgraded. They must be given continuous encouragement to be motivated and guidance and direction so that they are not easily influenced by the times.

The process of implementing learning activities also determines whether it is easy or difficult for students to absorb the knowledge conveyed by educators. Before the COVID-19 pandemic, university teaching was conducted face-to-face. However, now requires the process of teaching and learning activities from home or online. Students are required to stay active in learning and take part in virtual classroom activities. Online learning involves internet networks, modules, other sources from the internet, and the desire to keep the spirit of understanding. Lecturers must always provide encouragement and motivation to students to continue taking online classes.

According to Oktiani (2017), in the learning activities, motivation can be defined as the overall driving force in students that causes learning activities to ensure the continuity of these learning activities and provide learning direction so that the learning objectives in students learning are achieved. Motivation is needed to increase the enthusiasm for learning in students so that learning activities can run well. Learning motivation is one of the critical success factors in achieving the learning process. With learning motivation, students are increasingly motivated to be enthusiastic about participating in the learning process. Educators make various kinds of ways and efforts to foster learning motivation in students. Based on Pintrich (Mayasari, 2015), there are two types of motivation: intrinsic and extrinsic. Intrinsic motivation comes from within a person or the urge to be involved in an activity without being forced by people for the activity itself, for example, in learning (Mulyana, 2020). While motivation comes from outside, for example, is when someone is studying, knowing that tomorrow morning there will be an exam in the hope of getting good grades or getting a prize (Djamarah, 2002).

In this study, the author discusses students' motivation to learn English online at private universities in Yogyakarta. The aspects studied in this study are four aspects of learning motivation indicators, including Attention, Relevance, Confidence, and Satisfaction, abbreviated as ARCS.

This study aims to determine and describe the motivation for learning English online for students at private universities in Yogyakarta. The research seeks to accurately describe student 
learning motivation in learning English online during the COVID-19 pandemic. It is hoped that educators can improve the quality of more creative learning by using various online learning methods or techniques during the COVID-19 pandemic. For lecturers, this research is expected to improve the quality of learning, be more creative in attracting students to encourage students to continue learning online. For students, it can motivate them to keep learning and make the best use of online learning media. For universities, it can evaluate the learning implementation process in preparing future learning plans by linking online learning media to increase student learning motivation to achieve maximum results. Furthermore, readers are expected to add insight related to online learning media. Meanwhile, for further researchers, it is hoped that it will be used as a reference in continuing further research related to the motivation of learning English online.

\section{LITERATURE REVIEWS}

Based on Hamalik (2014), motivational functions, among others: 1) Encourage the emergence of action; 2) Lead to actions to achieve the desired goal; 3) Mover, which means driving learning. Motivation is a state that influences the decision to act, do something. Motivation is the drive-in humans to cause the individual to initiate and maintain action directed at certain goals (Jenkins, 2018). Motivation can be seen as a driver in accomplishing achievement in learning. So, students are always required to determine the steps that must be taken to achieve learning goals.

A similar theory was also expressed by Long et al. (2013), which stated that there are four aspects of motivation to learn English, namely one's goals in learning, the existence of an effort to learn, the desire to achieve goals, and attitudes in education. Indicators of learning motivation include passion and desire to succeed, encouragement and need for learning, future hopes and aspirations, appreciation in learning, exciting activities in learning, and a conducive learning environment so that it is possible to learn well (Uno, 2010).

Keller (1987) developed an aspect to measure the level of student learning motivation called ARCS. Confidence is a strategy to help students build positive thinking to achieve learning success. Satisfaction is a strategy to give intrinsic and extrinsic rewards. Furthermore, (Trisnawati, 2008) explained four strategic components in motivating the ARCS model. Attention is a strategy to stimulate and arouse curiosity and interest. Relevance is a strategy to connect the needs, interests, and motives of students. Confidence is a strategy to help students 
build positive thinking to achieve learning success. Satisfaction is a strategy to provide extrinsic and intrinsic rewards.

Based on the description above, it can be concluded that motivation is an encouragement given to others and causes the motivated person to be more enthusiastic in working and having a sense of enthusiasm to achieve maximum results. In addition, motivation is also an impetus to do something that comes from within a person in the form of an awareness of the importance of something that must be done.

As is known, the conditions and situations in society require the Indonesian people to equip themselves to compete in the field of science and technology as an independent nation towards the era of globalization. English is part of the most widely used global communication tool to communicate with foreign countries. Oktavia et al. (2018) explained that a language is a communication tool in the form of sound symbols produced by human speech. Language is not only a science that is learned but also something that people use every day. Language is part of a communication tool, so it is necessary to be aware of the meanings of language that need to be mastered by knowledge (Saragih, 2015). According to Halliday (1985 as cited in Jatmiko et al., 2017), There are two kinds of meaning contained in all languages. Ideational meaning and interpersonal meaning. Ideational is a manifestation of one's experience, both experienced in the real world and the imaginary world or called "in the sense of content" ( Halliday, 1985 as cited in Halim, 2019). Interpersonal is behavior (as a speaker or writer) that we address to others (Saragih, 2015).

Learning English is essentially a science that teaches students to communicate in that language orally and to write. Cahyono (2020) said that Communication is understanding and expressing information, thoughts, feelings and developing science, technology, and culture. The ability to communicate is to understand and produce spoken or written texts realized in four language skills: listening, speaking, reading, and writing (Suyanto, 2013).

Technological developments are increasingly developing in various fields, especially in the field of education, so they must be responded to positively and adaptively in responding to the challenges of the 21 st century, which are full of complexity (Christian et al., 2020). The increasing use of technology in the modern era in education has become a sophisticated facility in various activities (Orgaz et al., 2018). The existence of technology for the world of education is a means that should be used as a medium for delivering learning programs both unidirectionally and interactively (Yusril, 2019). Educational institutions during the COVID19 pandemic require teachers and students to carry out online learning activities, meaning that 
teaching and learning activities continue to run but are carried out from home (Basar, 2021). The use of technology has enabled the emergence of distance learning and is driving more significant innovation in creating teaching methods inside and outside the classroom (Fitriyani et al., 2020).

Online learning demands to be more motivated in learning. Motivation and characteristics are curiosity involving the learning process. According to hammer in Kholid (2017), the motivation that drives a person to learn English is influenced by the community's attitudes in which they are or live, the people close to them, including the teacher, and the methods he uses in the learning process. Motivation is considered a significant factor in successful learning, including in the online learning process, so it is necessary to reconsider learning motivation in learning environments that utilize technology. For this reason, researchers in the world of education need to study in-depth how students motivate online learning, mainly when learning activities are carried out during the COVID-19 pandemic.

Based on the description above, it can be concluded that it is vital to have an online learning strategy to increase learning motivation for students. Sugiyanto (2012) stated that motivation is an essential factor in the learning process to achieve the expected achievement. For online learning to run effectively, educators need to pay attention to it seriously, such as providing material before assignments, giving assignments accompanied by clear instructions, and reducing assignments (Setiono et al., 2021). Achievement is a driving factor for business in an attitude that is directed and can maintain its achievements. Likewise, students who do not have a strong learning motivation will not be able to carry out learning activities in the learning process, and their academic achievement will be below. On the other hand, if students have a strong learning motivation, they will do well in learning activities and have the best academic achievement results.

\section{METHODOLOGY}

This study is quantitative research. It was conducted from September 2020 to February 2021 in Yogyakarta, Indonesia. The population in this study was students consisting of three private universities (campus) in Yogyakarta. A sample is a part of the population (Arikunto, 2015). The sample was selected through the purposive sampling method. The samples in this study were students of the Management study program at AMA Yogyakarta, students of the Accounting Information System study program at STMIK Akakom, students of the Information Systems study program at STMIK Akakom, and students of the Public Health 
study program at STIKES Wira Husada. From each university, 32 students were taken as samples. So, the total sample is 128 students.

Data collection techniques were questionnaires, interviews, and observations. The questionnaire was distributed by students and given via a google form. The reason was as the research was conducted during the COVID-19 pandemic, face-to-face learning was abolished but carried out with online learning. Interviews were conducted with lecturers of English courses at Yogyakarta universities. The observation technique was done by observing students during the learning process. Observations were made during learning through the WhatsApp group or Google Meet.

Triangulation was used to validate the data. The research instrument was an armature sheet and an interview sheet in the form of several questions and written questions regarding the motivation for learning English online. The measurement of motivation is based on the ARCS aspect, which is further developed in several indicators. The data analysis technique is descriptive quantitative. Likert scale with four answer choices was used as the scoring method: score 1: never, score 2: rarely, score 3: sometimes, and score 4: always. The categories of motivation for learning English: low, medium, and high can be seen in table 1.

Table 1. Categories of measurement of motivation in learning English

\begin{tabular}{ccc}
\hline No. & Score Range & Category \\
\hline 1. & $\mathrm{X} \geq \bar{X}+\mathrm{SD}$ & High \\
2. & $\bar{X}-\mathrm{SD} \leq \mathrm{X} \leq \bar{X}+\mathrm{SD}$ & Medium \\
3. & $\mathrm{X} \leq \bar{X}-\mathrm{SD}$ & Low \\
\hline
\end{tabular}

Note:

$\mathrm{X}$ : Score of motivation to learn English for each student

$\bar{X}$ : Standard deviation of English learning score

The results of these calculations obtained learning categories that can be grouped into high, medium, low. Determination of the percentage $(\%)$ of each category of motivation to learn English is as follows:

$$
A=\frac{\mathrm{N}}{\mathrm{T}} \times 100 \%
$$

Note:

A: Categories of a high, medium, and low learning motivation

$\mathrm{N}$ : The number of students who have high, medium, and low learning motivation

T: The research sample or the number of students from the questionnaire data on the motivation to learn English from these students has then calculated the percentage of each aspect. 
How to calculate it with the following formula:

$$
M=\frac{\mathrm{X}}{\mathrm{Y}} \times 100 \%
$$

Note:

M: Percentage of each aspect of the learning motivation questionnaire (ARCS)

$\mathrm{X}$ : Scores from aspects of Attention, Relevance, Confidence, and Satisfaction

Y: Ideal score from the aspects of Attention, Relevance, Confidence, and Satisfaction.

Experts will validate the questionnaire before being tested by students. The goal is to see reliability. This content validation is to see the suitability of the indicator with aspects of learning motivation and content of the sentence composition contained therein. After confirmation, a questionnaire from the expert will then be given to students. Meanwhile, the observation sheets were analyzed qualitatively. Data analysis techniques in this study are 1 . Data reduction, 2. Data presentation, and 3. Conclusion.

\section{RESULTS AND DISCUSSION}

The use of questionnaires for students and interviews with lecturers about motivation to learn English is based on indicators including ARCS. The motivation questionnaire that has been validated is then tested on 40 even semester students at AMA Yogyakarta. Indicators of motivation for learning English are presented in table 2. The percentage of results obtained is illustrated in the bar chart presented in chart 1.

Table 2. Indicators of learning motivation

\begin{tabular}{cll}
\hline No. & Aspect & \multicolumn{1}{c}{ Indicators } \\
\hline 1. & Attention & $\begin{array}{l}\text { Attention to the learning process. The willingness of students to } \\
\text { seek and find information related to learning English. }\end{array}$ \\
2. & Relevance & $\begin{array}{l}\text { Able to relate various concepts from the material. Mention English } \\
\text { language skills in daily life. }\end{array}$ \\
3. & Confidence & $\begin{array}{l}\text { Dare to convey ideas or answer questions. Make decisions in every } \\
\text { problem related to problems in English language skills. }\end{array}$ \\
4. & Satisfactions & $\begin{array}{l}\text { Try to be active in English learning activities. Do assignments, } \\
\text { quizzes, and practice questions. }\end{array}$ \\
\hline
\end{tabular}

The questionnaire on motivation to learn English shows a reliability value with Cronbach's Alpha of 0.844 . It means that the items in the questionnaire show high reliability. Because during the COVID-19 pandemic, the distribution of motivational questionnaires for learning English online was given to students via Google form. 
The motivation for learning English is grouped into three categories, namely high, medium, and low. The grouping aims to make it easier for researchers to see categories of motivation in students. From 128 students, it is known that the number of students in the category of online English learning motivation can be seen in table 3 .

Table 3. Categories of students' motivation for learning English

\begin{tabular}{ccc}
\hline No. & Categories & Students Number \\
\hline 1. & High & 24 \\
2. & Medium & 72 \\
3. & Low & 32 \\
\hline & Total & 128 \\
\hline
\end{tabular}

Based on table 3, 128 students in Yogyakarta have different motivations for learning English. There are 24 students in the high category, 72 in the medium category, and 32 in the low learning motivation category. The results of data analysis make a percentage for each category of motivation to learn English, namely the motivation to learn English in the high category as much as $18.75 \%$, the medium category $56.25 \%$, and the low category as much as $25 \%$. Based on these results, it is known that the motivation is categorized as moderate.

Chart 1. Categories of motivation for learning English

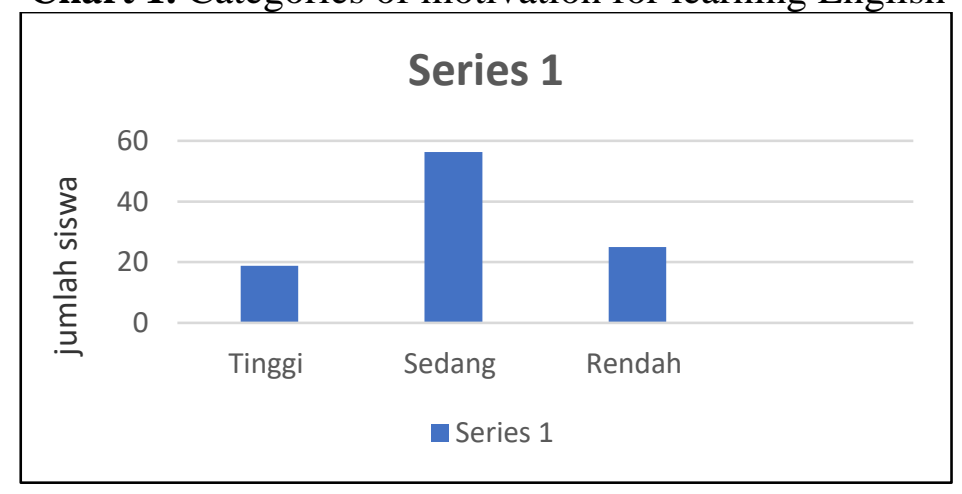

The research results shown in chart 1 are most of 2020/2021 even semester students have moderate category motivation in learning English online. Most students who take English lectures still find it challenging to learn English online. This is due to various factors from within the students themselves, friends, and their environment. Learning English, which is carried out online during the COVID-19 pandemic, has positively impacted students and educators. Students should learn more independently and not rely on anyone but find reference books themselves or the internet. Educators must choose and determine what learning media 
are accepted and can be used in teaching to effectively use the method for learning English and form of learning evaluation.

Various platforms educators use in carrying out English learning on campus are WhatsApp, Google Classroom, Google Meet, and Zoom meeting. The goal is that learning activities can be carried out well and varied for the students not to feel bored. There are obstacles in online learning, one of which is difficulty in the internet network because some students are in rural areas where signals are difficult. Zoom meetings or Google Meet as virtual media are most often used instead of face-to-face.

It is important to know students' learning motivation in English courses to find further solutions to existing problems. Based on the results of the study that Satisfaction gets the most from other aspects. This is shown to students in their courage to answer questions from educators during online lectures using Zoom meetings or Google Meet. Still, students' answers are sometimes incorrect (not by the answers to questions given by educators). This is because students are less enthusiastic about finding sources of information from various sources that are updated and do not apply the material to everyday life. Students find it difficult to listen due to unstable network problems when viewing video or audio data. Essential competencies of reading, speaking, writing, and listening skills are difficult for students. The various causes of the difficulty of the four skills are due to the low motivation of students to learn.

Students of the Accounting Information System study program at STMIK Akakom have low motivation to learn English following the Relevance aspect of 20\%. Students on campus are enthusiastic about learning English, but students are not optimal in linking English learning materials in daily life; students find it difficult to speak English. This difficulty contributes to being less skilled in speaking English in everyday life, for example, speaking in English and writing in English. Lecturers prefer to use Google Classroom in learning English in which they present material, both learning videos or modules, and assignment instructions at the end of the meeting. From the results of the student questionnaire, it was concluded that students felt bored when the tasks were given for each meeting. Assignments were usually given through Google Classroom or easy lessons delivered in the WhatsApp group and then uploaded in Google Classroom. However, sometimes the instructions for students were unclear, resulting in students not being able to carry out their duties while they wanted to confirm to the educator. But, students did not dare to convey it to the educator.

The Information Systems study program also experiences students' difficulties in paying attention to English courses. When virtual learning began, students did not join right away. 
Still, many students were late for class because the network was unstable, even though the educator had distributed the link 15 minutes before the lecture started. Students are less interested when doing learning that has to answer many questions from educators. Educators give assignments to students related to English material about the latest information technology, and then the students analyze it. In this case, students lack confidence in what they are doing because analyzing a problem in English is not easy. Educators can see that the reason for this is that students are less motivated, less enthusiastic, and not looking for information related to the learning material. According to most students in the Information Systems study program, the Attention aspect is as much as $20 \%$ becomes the lowest aspect.

The aspect of Confidence of students of the Public Health study program at STIKES Wira Husada is as much as $23 \%$ with low motivation to learn English. Based on the results of interviews with English lecturers at STIKES Wira Husada, found that lecturers often noticed students felt bored when implementing English language learning. It can be seen when the learning process took place. Most of the students did not have the desire to answer the questions that the educator had given. Students were often late for virtual classes.

At the time of learning, more students were silent and did not respond to feedback or ask questions; they chatted when the educator explained the material; some students tried to find answers but did not dare to reply in the forum. This factor causes less opportunity to argue so that students feel less confident while educators explain more about theory. In addition to using virtual classes with Zoom or Google Meet, lecturers use e-campus or applications provided by the campus to provide materials or assignments. As for assignments, they are usually given at the campus and then collected according to the schedule. Students' answers were collected through e-campus, but there was never any feedback or discussion about what the students had done. The result is not knowing that what is done is the right or wrong answer. However, students are also not punctual when submitting assignments. There were often some students who ignored the assignments given, so they did not submit them. This is because students' learning motivation in the form of Attention to English learning is low.

The Satisfaction aspect of the motivation for learning English is low, with as much as $35 \%$ of the Management study program students. It is shown that students are trying to answer questions and collect assignments from educators in English actively.

The determination to submit assignments through Google Classroom is very good to be accepted. Many students submitted assignments on the last day of the assignment submission deadline. This means that no one is late in submitting assignments, but it is undeniable that 
there are still many answers from students that are less precise in answering the questions given. It is known that students are less attentive and have not explored current information related to learning English. Students' attention in looking for other sources of information is also still low, so the answers written by students are still not entirely correct. Students' responses are not based on logic and lack clear information or references. Students are only active in assignments in the form of quizzes or other assignments. It must be further instilled in students to use logical and critical thinking to overcome various problems. Students' motivation in learning English is measured in every aspect of ARSC, which can be seen in table 3 .

Table 3. Aspects of student motivation in learning English online

\begin{tabular}{|c|c|c|c|c|c|c|}
\hline \multirow[t]{2}{*}{ Aspect } & \multirow[t]{2}{*}{ Indicators } & \multicolumn{4}{|c|}{$\begin{array}{l}\text { Name of Campus Study } \\
\text { Program and Number of } \\
\text { Motivational Aspects (\%) } \\
\end{array}$} & \multirow[t]{2}{*}{$\begin{array}{c}\text { Total } \\
(\%)\end{array}$} \\
\hline & & 1 & 2 & 3 & 4 & \\
\hline $\mathbf{A}$ & $\begin{array}{l}\text { Attention to the learning process. The willingness } \\
\text { of students to seek and find information related to } \\
\text { learning English. }\end{array}$ & 26 & 22 & 20 & 18 & 21.5 \\
\hline $\mathbf{R}$ & $\begin{array}{l}\text { Able to relate various concepts from the material. } \\
\text { Mention English language skills in daily life. }\end{array}$ & 22 & 31 & 25 & 20 & 24.5 \\
\hline C & $\begin{array}{l}\text { Dare to convey ideas or answer questions. Make } \\
\text { decisions in every problem related to problems in } \\
\text { English language skills. }\end{array}$ & 32 & 26 & 25 & 20 & 25.75 \\
\hline $\mathbf{S}$ & $\begin{array}{l}\text { Try to be active in English learning activities. } \\
\text { Do assignments, quizzes, and practice questions. }\end{array}$ & 23 & 30 & 26 & 34 & 28.00 \\
\hline
\end{tabular}

Note:
A: Attention
1: Accounting Information System
R: Relevance
2: Information Systems
C: Confidence
3: Public Health
S: Satisfaction
4: Management

The acquisition from several private universities in Yogyakarta in every aspect of student motivation in learning English online: Attention is $21.5 \%$, Relevance is $24.5 \%$, Confidence is $25.75 \%$, and Satisfaction is $28 \%$. The results show that the Attention aspect is the lowest and the Satisfaction aspect is the highest. The acquisition of every aspect of motivation to learn English is presented in chart 2. 
Chart 2. The acquisition of every aspect of motivation for learning English online

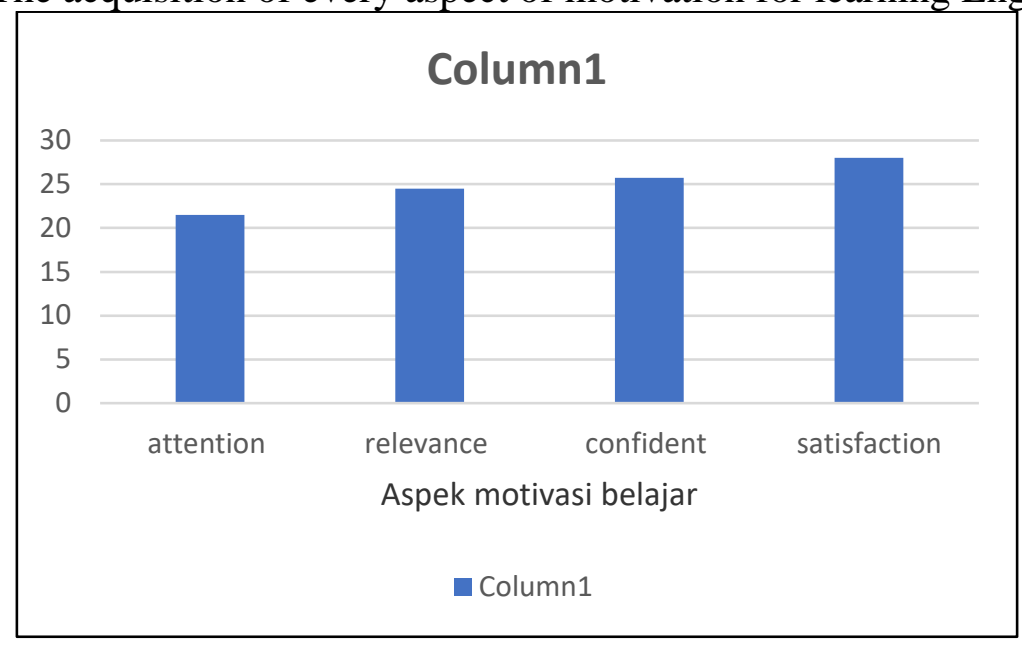

Indicators of Attention on the motivation of students' desire to learn English is low with learning using Zoom, Google Meet, and others. At the time of virtual learning (Zoom meeting), many students are not focused. When asked, some students did not want to respond to the answer but must be appointed by the educator first, then some students answered. When a student was assigned to answer, the student answered. But the answer was incorrect, and the student seemed not to focus on learning English. The will to find information or knowledge related to language skills is still not fully implemented. It is proven when educators asked students to read books or look for information before learning, but not all students did it, and some even opened it during the lecture. When there was a group presentation task, some students did not just pay attention to what was said by the group in charge of the presentation, so the discussion was not conducive until the end of the lecture. During the Zoom meeting or Google Meet, some students entered the virtual class late and often went in and out of the virtual class because the network was unstable or had poor signal.

Confidence (confident) indicator, among others, shows the courage of students to express opinions, both when asking questions to educators, answering questions given by educators, class discussions, group discussions, and presenting in presentations. More than $50 \%$ of students are more silent when asked to convey their ideas or opinions. Students seem to feel afraid of being wrong and embarrassed if they are wrong in answering or sharing their thoughts. Therefore, educators must allow students to express their opinions more often to hone students' views in class and increase individual assignments requiring students to speak in both virtual and face-to-face classes.

The last indicator is Satisfaction achieved by students by $60 \%$. The Satisfaction in question is the student's effort to be active in learning English in the classroom. This can be 
seen from some students doing the assignments given by the educator completely. The educator can do this aspect of Satisfaction to encourage students to study harder and achieve optimal learning goals. The results of filling out questionnaires conclude that most students are not satisfied with online learning in terms of learning methods, learning techniques, learning media, and learning outcomes.

The purpose of learning English must be continuously pursued so that students can achieve these learning goals. The encouragement of self-study motivation is very important because motivation greatly affects the cognitive outcomes of students. Motivation can arise from oneself, others, or the environment-factors such as enthusiasm and interest in learning English subjects. Various factors from educators are related to the methods, techniques, strategies, models, and learning media used by educators in the process of learning English. In addition, the curriculum and how to evaluate students also affect student motivation in the implementation of learning. The attention and guidance of lecturers during the implementation of learning also affect students in learning. Lecturers who pay attention to and guide students both in and outside will make students happier and feel comfortable until finally motivated to take part in learning. Factors from the environment may be due to an unsupportive and unfavorable situation during the COVID-19 pandemic.

\section{CONCLUSION}

Based on the results of data analysis on student learning motivation at private universities in Yogyakarta during the COVID-19 pandemic, it is concluded that the category is moderate. At the beginning of online learning, students had very low motivation because students and educators were not ready to use technology. But over time, students and educators get used to using technology, although they still do not master it. Various factors that cause motivation to learn English can be seen from four aspects: Attention, Relevance, Confidence, and Satisfaction. The four aspects show that Satisfaction is the highest aspect with $28 \%$, while Confidence is 25.75 , Relevance is $24.5 \%$, and the lowest aspect is Attention with $21.5 \%$.

\section{REFERENCES}

Arikunto, S. (2015). Prosedur penelitian. Kencana.

Basar, A. M. (2021). Problematika pembelajaran jarak jauh pada masa pandemi COVID-19. Edunesia: Jurnal Ilmiah Pendidikan, 2(1), 208-218. https://doi.org/10.51276/edu.v2i1.112 
Cahyono, A. D. (2020). Membangun komunikasi efektif dalam menentukan keberhasilan pembelajaran.

http://p4tkboe.kemdikbud.go.id/bbppmpvboe/berita/detail/membangun-komunikasiefektif-dalam-menentukan-keberhasilan-pembelajaran

Christian, Y., Robin, Aziz, M. F., Kencana, R. T., Exendy, R. R., Triputra, R., Tjiam, S., Rani, T., \& Afnesia, U. (2020). Pembelajaran bahasa Inggris secara daring melalui youtube. National Conference for Community Service Project (NaCosPro), 2(1), 478-486. https://journal.uib.ac.id/index.php/nacospro/article/view/1217

Djamarah, S. B. dan A. Z. (2002). Strategi belajar mengajar. Rineka Cipta.

Fitriyani, Y., Fauzi, I., Sari, M. Z. (2020). Motivasi belajar mahasiswa pada pembelajaran daring selama pandemik COVID-19. Jurnal Kependidikan: Jurnal Hasil Penelitian Dan Kajian Kepustakaan Di Bidang Pendidikan, Pengajaran Dan Pembelajaran, 6(2), 165-175. https://doi.org/10.33394/jk.v6i2.2654

Halim, F. (2019). Penggunaan metode mind mapping sebagai upaya untuk meningkatkan kompetensi writing teks descriptive siswa pada MTsN Langsa. At-Tarbawi: Jurnal Pendidikan, Sosial dan Kebudayaan, 6(2), 188-201. https://doi.org/10.32505/tarbawi.v6i2.1281

Hamalik, O. (2014). Kurikulum dan pembelajaran. Bumi Aksara.

Jatmiko, H. T. P., Setiawan, B., \& Sulistyo, E. T. (2017). Fungsi bahasa dalam wacana lisan transaksi jual beli di pasar Klewer Surakarta dan relevansinya sebagai materi pembelajaran bahasa Indonesia di SMA. Proceedings Education and Language International Conference, 359-375.

Jenkins, K. D. (2018). Understanding teacher beliefs and instructional decision making concerning disciplinary literacy: the case of secondary teachers in an urban school. International Journal of Learning, Teaching and Educational Research, 17(1), 175196. https://doi.org/10.26803/ijlter.17.1.11

Keller, J. M. (1987). Development and use of the ARCS model of instructional design. Journal of Instructional Development, 10(3), 2. https://doi.org/10.1007/BF02905780

Kholid, I. (2017). Motivasi dalam pembelajaran bahasa asing. English Education: Jurnal Tadris Bahasa Inggris IAIN Raden Intan, 10(1), 61-71.

Long, C., Ming, Z., \& Chen, L. (2013). The study of student motivation on English learning in junior middle school -- a case study of no.5 middle school in Gejiu. English Language Teaching, 6(9), 136-145. https://doi.org/10.5539/elt.v6n9p136

Mayasari, D. (2015). Pengaruh orientasi tujuan dan motivasi belajar terhadap prestasi belajar siswa SMA peserta bimbingan belajar LBB Primagama. UIN Syarif Hidayatullah Jakarta.

Mulyana, A. (2020). Motivasi belajar siswa, pengertian bentuk dan faktor yang mempengaruhi motivasi belajar siswa. https://ainamulyana.blogspot.com/2012/02/motivasibelajar.html 
Oktavia, I., Sukandi, P. I. I., Chalid, R. I., Selani, T. P., Kuntarto, E., \& Noviyanti, S. (2018). Hakikat bahasa sebagai alat kontrol sosial. 1-9.

Oktiani, I. (2017). Kreativitas guru dalam meningkatkan motivasi belajar peserta didik. Jurnal Kependidikan, 5(2), 216-232. https://doi.org/10.24090/jk.v5i2.1939

Orgaz, F., Moral, S., \& Domínguez, C. (2018). Student's attitude and perception with the use of technology in the university. Journal of Educational Psychology - Propositos y Representaciones, 6(2), 277-299.

Saragih, R. S. (2015). Kebutuhan komunikasi berbahasa Inggris. https://analisadaily.com/berita/arsip/2015/11/23/190828/kebutuhan-komunikasiberbahasa-inggris/

Setiono, P., Dadi, S., Yuliantini, N., Anggraini, D., \& Bengkulu, U. (2021). Analisis respon mahasiswa terhadap pelaksanaan pembelajaran daring. Jurnal Education and Development, 9(2), 19-23. https://doi.org/https://doi.org/10.37081/ed.v9i

Sugiyanto. (2012). Pentingnya motivasi berprestasi dalam mencapai keberhasilan akademik siswa. Universitas Negeri Yogyakarta, 1-15. http://universitas.widyamandala.ac.id/index.php?option=com_content\&view=article\& $\mathrm{id}=336$ :pentingnya-motivasi-berprestasi\&catid=65:krida-rakyat

Suyanto, K. K. E.(2013). Hakikat pembelajaran bahasa Inggris untuk anak (EYL). English for Children (1-40). Universitas Terbuka. http://repository.ut.ac.id/id/eprint/3969

Trisnawati. (2008). Implementasi model ARCS (Attention, Relevance, Confidence, Satisfaction dalam pembelajaran PAI di SMA N 1 Brebes. IAIN Walisongo Semarang.

Uno, H. B. (2010). Teori motivasi dan pengukurannya. Bumi Aksara.

Yusril, F. P. (2019). Pemanfaatan teknologi informasi dalam bidang pendidikan (Eeducation). 2(1). https://doi.org/10.31219/osf.io/ycfa2 